DOI: http://dx.doi.org/10.54085/ap.covid19.2021.10.2.14
Annals of Phytomedicine: An International Journal
http://www.ukaazpublications.com/publications/index.php
Print ISSN : 2278-9839 Online ISSN : 2393-9885

\title{
A scoping review on herbs and spices with special reference to COVID-19 pandemic
}

Sunil, Shweta Sharma, K.P. Kochhar and Suman Jain

Department of Physiology, All India Institute of Medical Sciences, New Delhi-110029, India

\section{Article Info}

\section{Article history}

Received 1 November 2021

Revised 15 December 2021

Accepted 16 December 2021

Published Online 30 December 2021

Keywords

COVID-19 pandemic

SARS-CoV-2

Herbs and spices

Immunity

Medicinal plants

Antimicrobial

\begin{abstract}
The world is facing medical crisis due to the pandemic created by COVID-19. Due to COVID-19, not only our country but the whole world is passing through economic crisis also. As there is no specific treatment for the infection caused by SARS-CoV-2 and it affects the people with weak immunity more adversely so, many people including scientists are looking forward to increase the immunity by using medicinal plants, i.e., herbs and spices. Vitamin $\mathrm{C}$ is also being widely used by the doctors across the world to increase the immunity, but as herbs and spices are easily available and have been widely used as antimicrobial and anti-inflammatory agent since ancient time so, they can be used both as effective immunity booster as well as antiviral agent as shown by some compounds found in the herbs and spices.
\end{abstract}

\section{Introduction}

In December 2019, people from Wuhan city of China were identified as suffering from pneumonia like viral disease. The virus was named as SARS-CoV-2 by ICTV on February 11, 2020. And the disease was named as coronavirus disease, COVID-19 by WHO on the same day. Soon the cases start to increase rapidly and WHO declared it as PHEIC, Public Health Emergency of International Concern on $30^{\text {th }}$ January, 2020 and then as global pandemic on $11^{\text {th }}$ March, 2020. Some symptoms of the disease are dry cough, fever, diarrhea, shortness of breath, respiratory distress, etc. The treatment of the disease involves the symptomatic release of the symptoms and there is specific treatment for the disease. So, many researchers are interested for the use of herbs and spices which have potency against the viruses as well as increase the immune power of the person. Here are some of the common herbs and spices which have been evaluated for their use against the COVID-19 (Tian et al., 2020).

\section{Some important herbs found to be effective against COVID-19}

\subsection{Ashwagandha (Withania somnifera)}

Ashwagandha is found to be very effective against the cardiovascular diseases, neurodegenerative disorders, asthma and cancer by altering the level of leucocytes, lymphocytes, neutrophils, immune complexes and immunoglobulins (Ig) A, G and M. In COPD, it reduces the tiredness, coughing and breath lessness. Further more, it reduces the pulmonary fibrosis also.

Corresponding author: Dr. K.P. Kochhar

Professor, Department of Physiology, All India Institute of Medical Sciences, New Delhi-110029, India

E-mail: kpkochhar06@gmail.com

Tel.: +91-9871859100

Copyright () 2021 Ukaaz Publications. All rights reserved.

Email: ukaaz@yahoo.com; Website: www.ukaazpublications.com
Withanone, a compound from Withania somnifera also interferes with the binding of COVID-19 to host cell ACE2 through RBD (Receptor Binding Domain) of its spike protein and, thus decreasing its efficacy to enter into the host cell (Kaur et al., 2015; Bale et al., 2018; Balkrishna et al., 2020; Murlikrishna et al., 2021).

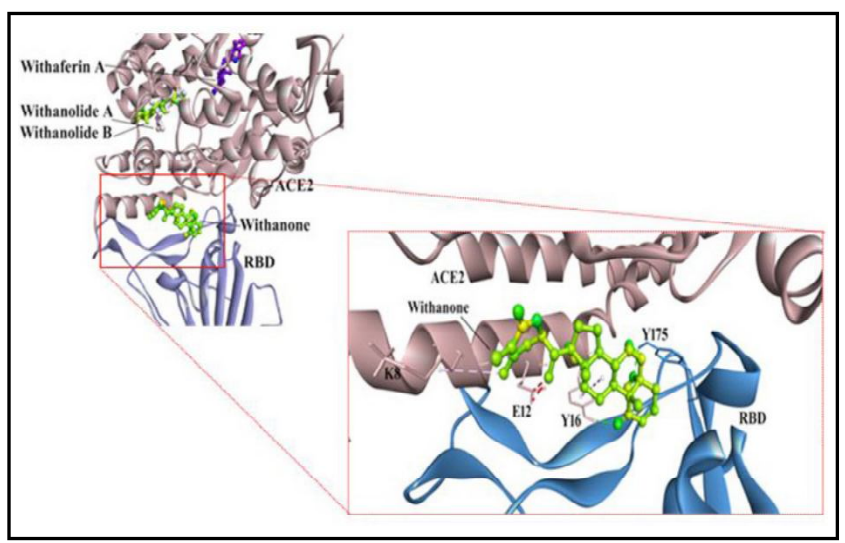

Binding of withanone with ACE2-RBD complex.

\subsection{Giloy (Tinospora cordifolia)}

Giloy is having both antimicrobial as well as immunostimulant properties. It is found to be very effective against fever including dengue, jaundice, asthma and inflammations including arthritis and gout and tuberculosis. It is found to have antiviral properties especially against retroviruses like HIV, HSV, etc.

Tinocodiside, a compound from giloy, interferes with the binding of COVID-19 to host cell ACE2 through RBD (Receptor Binding Domain) of its spike protein and, thus decreasing its efficacy to enter into the host cell similar to that of withanone from ashwagandha (Sinha et al., 2004; Mishra et al., 2012; Gupta et al., 2016; Sharma et al., 2019). 


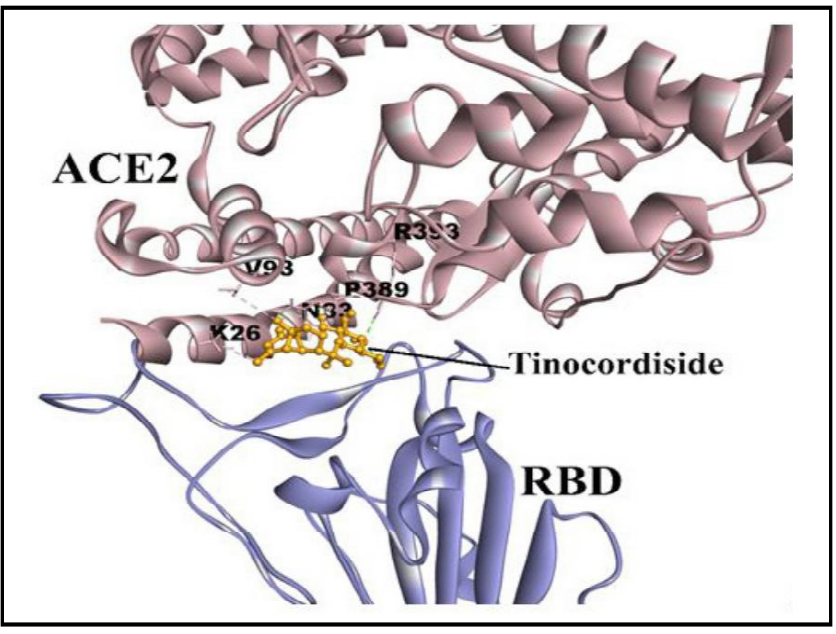

Interactions (docking) of tinocodiside with ACE2-RBD complex.

\subsection{Tulsi (Ocimum sanctum)}

Tulsi is rich in the medicinal properties, i.e., why it is also known as "Mother Medicine of Nature"and "Queen of Herbs" as it is having antimicrobial, antipyretic, anti-inflammatory, antiallergic, broncho-dilator as well as neuro- and cardio-protective properties.

Scutellarein, a compound from tulsi is found to be very effective against the viruses. It is also an inhibitor of SARS-CoV helicase, an enzyme essential for the replication of the SARS-CoV-2 virus, the causative agent of COVID-19 (Priyabrata et al., 2010; Mahajan et al., 2013; Cohen, 2014; Pandey et al., 2015; Bhalla et al., 2017; Vinaya, 2017; Meghwani, 2018)

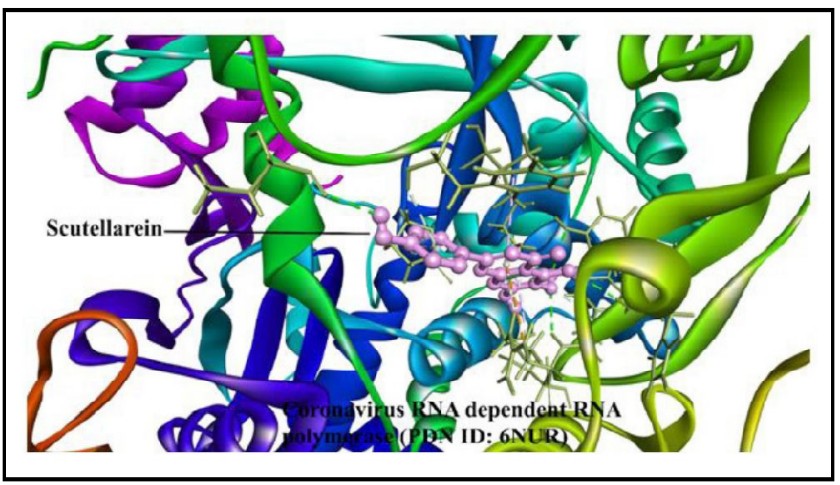

Docking of scutellarein in catalytic cleft of RDRP.

\subsection{Neem (Azadirachta indica)}

Neem declared as "Tree of the 21 st century" by UNEP, has been used extensively against several infections due to its antimicrobial properties. Hyperoside, a compound found in the leaves of the neem has potential against the influenza and, so it can be used against the ILI (Influenza Like Illness) like COVID-19 and has showed best results when used along with drugs like LGH, naproxen, BMS- 885838 , and BMS- 883559 with conserved residues of nucleoprotein of influenza virus (Ahmad et al., 2016). Along with tulsi, it acts as effective inhibitor of SARS-CoV-2 by inhibiting its attachment and replication.

\section{Some important spices found to be effective against COVID-19}

\subsection{Turmeric (Curcuma longa)}

Turmeric is categorized as "Generally Recognized as Safe" by FDA as it (curcumin) does not cause any side-effects or toxicity even at higher doses of 2,500 to 8,000 mg per day for 3 months (Irshad et al., 2017).

Curcumin, a compound from it shows anti-inflammatory, antiangiogenic, anti-neoplastic and antiviral properties. It acts as an inhibitor of replication of the virus. It also binds and inhibits the SARS-CoV-2 protease, spike glycoprotein RBD, and PD-ACE2, which are involved in virus infection.

\subsection{Ginger (Zingiber officinale)}

Ginger is called as sunthi in dry form and is one of the important medicinal plants in Ayurveda and herbal drug in Unani system. It shows antipyretic, antiemetic, analgesic, anti-inflammatory and antiviral properties.

Gingerenone A, gingerol, geraniol, shogaol, zingiberene, zingiberenol, and zingerone compounds from ginger interact with spike and main protease of SARS-CoV-2 and, thus showed anti-SARS-CoV-2 properties (Agrahari et al., 2015; Aboubakr et al., 2016 ; Yashin, 2017; Admas, 2020 ; Akham et al., 2020 ).

\subsection{Cinnanon (Cinnamomum cassia)}

Cinnanon possesses antimicrobial including antiviral, antioxidant, antihypertensive, antidiabetic properties. It is commonly used in fever, common cold, headache and throat infections. The bark of cinnamon contains 21 antimicrobial compounds, which include cinnamaldehyde $(60.41 \%)$ and eugenol (3.19\%).

Cinnamon increases the phagocytic index, serum immunoglobulin levels and titer of antibody at high dose $(100 \mathrm{mg} / \mathrm{kg})$ while in low dose $(10 \mathrm{mg} / \mathrm{kg})$, it increases the level of serum immunoglobulin. Thus, it increases both cellular and humoral immunity.

\subsection{Clove (Syzygium aromaticum)}

Clove is used as an antiseptic against due to its antimicrobial properties against oral bacteria. Clove is also used in the food industry due to its antimicrobial activities for increasing shelf-life. Use of clove as clove buds, clove oil, eugenol has been confirmed as safe by FDA. Daily uptake of clove in humans $(2.5 \mathrm{mg} / \mathrm{kg})$ has been considered acceptable in humans by WHO. Eugeniin, a compound from clove shows antiviral properties by inhibiting replication of the virus and its infection.

\subsection{Black pepper (Piper nigrum)}

Black pepper has antipyretic, antiasthmatic, antioxidant, antimicrobial and anti-Alzeimer properties and has been widely used in Ayurveda, Siddha, Unani, and Tibetan system of medicine (Irshad et al., 2017).

Piperine is the most important compound from it and has been found effective against Dengue and Ebola viruses. Whereas, piperanine and piperdardiine are thought to be effective against COVID-19. 


\section{Conclusion}

From the above discussion, we can conclude that herbs and spices are not only the immunity booster, but they can inhibit the entry of the virus and even inhibit the replication of the SARS-CoV-2 also. Also, ashwagandha, giloy and tulsi could be used together as they could work in tandem. Moreover, both humoral and cellular immunity would get increased by the use of herbs and, spices and thus would be beneficial for the patient of COVID-19.

\section{Conflict of interest}

The authors declare no conflicts of interest relevant to this article.

\section{References}

Aboubakr, H. A.; Nauertz, A.; Luong, N. T.; Agarwal, S.; El-Sohaimy, S.; Youssef, M. M. and Goyal, S. M. (2016). In vitro antiviral activity of clove and ginger aqueous extracts against feline calicivirus, a surrogate for human norovirus. Journal of Food Protection, 79(6):1001-1012.

Admas, C. (2020). Ginger fights multiple viral infections. The Journal of Plant Medicines https://plantmedicines.org/ginger-fightsmultiplevirus-infections

Agrahari, P.; Panda, P.; Verma, N. K.; Khan, W. U. and Darbari, S. (2015). A brief study on Zingiber officinale: A review. Journal of Drug Discovery and Therapeutics, 3(28):20-27.

Ahkam, A. H.; Hermanto, F. E.; Alamsyah, A.; Aliyyah, I. H. and Fatchiyah, F. (2020). Virtual prediction of antiviral potential of ginger (Zingiber officinale) bioactive compounds against spike and MPro of SARSCoV2 protein. Journal of Biological Researches, 25(2):52-57.

Ahmad, A.; Javed, M. R.; Rao, A. Q. and Husnain, T. (2016). Designing and screening of universal drug from neem (Azadirachta indica) and standard drug chemicals against influenza virus nucleoprotein. BMC Complementary and Alternative Medicine, 16:519.

Bale, S.; Venkatesh, P.; Sunkoju, M. and Godugu, C. (2018). An adaptogen Withaferin A ameliorates in vitro and in vivo pulmonary fibrosis by modulating the interplay of fibrotic, matricelluar proteins, and cytokines. Frontiers in Pharmacology, 9:248.

Balkrishna, A.; Pokhrel, S.; Singh, J. and Varshney, A. (2020). Coronavirus (COVID-19) entry by disrupting interactions between viral Sprotein receptor binding domain and host ACE2 receptor. BMC Virology. DOI:10.21203/rs.3.rs-17806/v1

Bhalla, G.; Kaur, S.; Kaur, J.; Kaur, R. and Raina, P. (2017). Antileishmanial and immunomodulatory potential of Ocimum sanctum Linn. and Cocos nucifera Linn. in murine visceral leishmaniasis. Journal of Parasitic Diseases, 41(1):76-85.

Cohen, M. M. (2014). Tulsi: Ocimum sanctum: A herb for all reasons. Journal of Ayurveda and Integrative Medicine, 5(4):251.

Gupta, P. K.; Chakraborty, P.; Kumar, S.; Singh, P. K.; Rajan, M. G.; Sainis, K. B. and Kulkarni, S. (2016). G1-4A, a Polysaccharide from tinospora cordifolia inhibits the survival of Mycobacterium tuberculosis by modulating host immune responses in TLR4 dependent manner. PloS One, 11(5):154-725.
Irshad, S.; Ashfaq, A.; Muazzam, A. and Yasmeen, A. (2017) Antimicrobial and anti-prostate cancer activity of turmeric (Curcuma longa L.) and black pepper (Piper nigrum L.) used in typical Pakistani cuisine. Pak. J. Zool., 49:1665-1669.

Kaur, G., Singh, N., Samuel, S. S., Bora, H. K., Sharma, S., Pachauri, S. D. and Hanif, K. (2015). Withania somnifera shows a protective effect in monocrotaline-induced pulmonary hypertension. Pharmaceutical Biology, 53(1):147-157.

Mahajan, N.; Rawal, S.; Verma, M.; Poddar, M. and Alok, S. (2013). A phytopharmacological overview on Ocimum species with special emphasis on Ocimum sanctum. Biomedicine and Preventive Nutrition, 3(2):185-192.

Meghwani, H.; Prabhakar, P.; Mohammed, S. A.; Dua, P.; Seth, S.; Hote, M. P. and Maulik, S. K. (2018). Beneficial effect of Ocimum sanctum (Linn) against monocrotaline-induced pulmonary hypertension in rats. Medicines, 5(2):34.

Mishra, A.; Gond, S. K.; Kumar, A.; Sharma, V. K.; Verma, S. K.; Kharwar, R. N., and Sieber, T. N. (2012). Season and tissue type affect fungal endophyte communities of the Indian medicinal plant Tinospora cordifolia more strongly than geographic location. Microbial Ecology, 64(2): 388-398.

Muralikrishnan, G.; Dinda, A. K. and Shakeel, F. (2010). Immunomodulatory effects of Withania somnifera on azoxymethane induced experimental colon cancer in mice. Immunological Investigations, 39(7):688-698.

Pandey, R.; Chandra, P.; Srivastava, M.; Mishra, D. K. and Kumar, B. (2015). Simultaneous quantitative determination of multiple bioactive markers in Ocimum sanctum obtained from different locations and its marketed herbal formulations using UPLC-ESIMS/ MS combined with principal component analysis. Phytochemical Analysis, 26:383-394.

Priyabrata, P.; Pritishova, B.; Debajyoti, D. and Panda, S. K. (2010). Ocimum sanctum Linn. A reservoir plant for therapeutic applications: An overview. Pharmacognosy Reviews, 4(7):95-105.

Sharma, P.; Dwivedee, B. P.; Bisht, D.; Dash, A. K. and Kumar, D. (2019). The chemical constituents and diverse pharmacological importance of Tinospora cordifolia. Heliyon, 5(9):e02437.

Sinha, K.; Mishra, N. P.; Singh, J. and Khanuja, S.P.S. (2004). "Tinospora cordifolia (Guduchi), a reservoir plant for therapeutic applications: A review". Indian Journal of Traditional Knowledge, 3(3):257270.

Tian, X.; Li, C, Huang, A.; Xia, S.; Lu, S.; Shi, Z. and Ying, T. (2020). Potent binding of 2019 novel coronavirus spike protein by a SARS coronavirus-specific human monoclonal antibody. Emerging Microbes and Infections, 9(1):382-385.

Vinaya, M. (2017). Bronchodilator activity of Ocimum sanctum Linn.(tulsi) in mild and moderate asthmatic patients in comparison with salbutamol: a single-blind cross-over study. International Journal of Basic and Clinical Pharmacology, 6(3):511.

Yashin, A.; Yashin, Y.; Xia, X. and Nemzer, B. (2017) Antioxidant activity of spices and their impact on human health: A review. Antioxidants, 6(3):70. 